\title{
Penerapan Model Pembelajaran Kooperatif Think Talk Write (TTW) dalam Pembelajaran Menulis Surat Pribadi pada Siswa Kelas VII SMP Pelita Kasih Kota Bengkulu
}

\author{
Marinir Tu Meilani Simanjuntak \\ Program Studi Pendidikan Bahasa Indonesia, Universitas Bengkulu \\ Email: marinirtumeilanis@gmail.com \\ Arono \\ Program Studi Pendidikan Bahasa Indonesia, Universitas Bengkulu \\ Email: arono@unib.ac.id \\ Noermanzah \\ Program Studi Pendidikan Bahasa Indonesia, Universitas Bengkulu \\ Email: noermanzah@unib.ac.id
}

\begin{abstract}
APA Citation: Simanjuntak, M. T. U., Arono, A., \& Noermanzah, N. (2021). Penerapan Model Pembelajaran Kooperatif Think Talk Write (TTW) dalam Pembelajaran Menulis Surat Pribadi pada Siswa Kelas VII SMP Pelita Kasih Kota Bengkulu. Silampari Bisa: Jurnal Penelitian Pendidikan Bahasa Indonesia, Daerah, dan Asing, 4(2), 213-230. https://doi.org/10.31540/silamparibisa.v4i2.1325
\end{abstract}

\begin{abstract}
Abstrak
Salah satu cara untuk memperbaiki kemampuan siswa dalam menulis surat pribadi yaitu dengan menerapkan model pembelajaran kooperatif think talk write. Tujuan penelitian ini untuk menggambarkan proses pembelajaran dengan menerapkan model pembelajaran kooperatif think talk write dan menggambarkan hasil belajar dengan menggunakan model pembelajaran kooperatif think talk write. Metode penelitian yang digunakan yaitu metode deskriptif dengan pendekatan kualitatif. Teknik pengumpulan data menggunakan teknik observasi dan dokumentasi. Teknik analisis data dalam penelitian ini menggunakan tiga langkah-langkah dalam menganalisis data yaitu mereduksi data, menyajikan data, dan menarik kesimpulan atau verifikasi. Uji keabsahan data menggunakan inter rater dan member check. Hasil penelitian menunjukkan bahwa langkah-langkah pembelajaran menulis surat pribadi dengan menggunakan model pembelajaran kooperatif think talk write yaitu, think (berpikir) dilakukan dengan cara memberikan bahan bacaan dan meminta siswa untuk menulis hal yang dianggap penting, talk (berbicara) dilakukan dengan cara guru membimbing siswa untuk melakukan diskusi mengenai hasil catatan siswa, dan write (menulis) dilakukan dengan cara meminta siswa untuk mengkontruksikan hasil yang telah diperoleh dari tahapan think (berpikir) dan talk (berbicara). Kemudian, hasil kemampuan siswa dalam menulis surat pribadi dengan menerapkan model pembelajaran kooperatif think talk write diperoleh nilai rata-rata sebesar 75,18 termasuk dalam kategori cukup.
\end{abstract}

Kata kunci : model pembelajaran kooperatif think talk write, pembelajaran menulis surat 
Marinir Tu Meilani Simanjuntak, Arono, Noermanzah

Penerapan Model Pembelajaran Kooperatif Think Talk Write (TTW) dalam Pembelajaran Menulis

Surat Pribadi pada Siswa Kelas VII SMP Pelita Kasih Kota Bengkulu

\title{
The Application of the Think Talk Write (TTW) Cooperative Learning Model in Learning to Write Personal Letters to Class VII Students of SMP Pelita Kasih Bengkulu City
}

\begin{abstract}
One way to improve students ability to write personal letters is to apply the think talk write cooperative learning model. The purpose of this study was to describe the learning process by applying the think talk write cooperative leraning model and to describe the learning outcomes using the think talk write cooperative learning model. The research method used is descriptive method with a qualitative approach. Data collection techniques using observation and documentation techniques. The data analysis technique in this study uses three steps in analyzing the data, namely reducing data, presenting data, and drawing conclusions or verification. Test the validity of the data using an inter rater and member check. The result showed that the steps of learning to write personal letters using the think talk write cooperative learning model, namely, think is done by giving reading matrial and asking students to write things that are considered important, talk is done by the teacher guiding students to conduct discussions about the results of student notes, and write is done by asking students to construct the results that have been obtained from the stages of think and talk. Then, the results of students ability to write personal letters by applying the think talk write cooperative learning model obtained and average value of 75,18 which was included in the sufficient category.
\end{abstract}

Keywords: think talk write cooperative learning model, learning to write letters

\section{A. Pendahuluan}

Model pembelajaran merupakan suatu konsep yang telah dirancang untuk menerangkan langkah demi langkah proses kegiatan pembelajaran secara lebih sistematis yang berguna untuk memperoleh suatu tujuan belajar yang ingin dicapai. Dalam model pembelajaran diharapkan proses kegiatan pembelajaran dapat berjalan dengan baik, menarik, dan menyenangkan (Octavia, 2020:13). Salah satu model pembelajaran yang dapat diterapkan, yaitu model pembelajaran kooperatif think talk write yang terdiri atas langkah-langkah yang terstruktur dan mudah untuk diterapkan dalam kegiatan proses pembelajaran. Model pembelajaran kooperatif think talk write adalah salah satu model pembelajaran yang dimulai dengan proses berpikir, berbicara, dan menulis.

Teori model pembelajaran kooperatif think talk write merupakan teori model pembelajaran yang dipelopori oleh Huinker dan Laughlin dalam (Huda, 2019:218) dan Hamdayama (2014:217) asumsinya bahwa pemahaman dalam belajar merupakan suatu tindakan sosial. Hal ini sejalan dengan pendapat Rabawati (2020:143) mengemukakan bahwa model pembelajaran kooperatif think talk write dapat membantu siswa untuk mengembangkan kecakapan siswa dalam berinteraksi secara sosial, hal ini terjadi karena model pembelajaran think talk write dapat meningkatkan semangat siswa untuk berinteraksi bersama siswa lainnya maupun dengan sumber belajar.

Sumayyah dkk., (2018:24) mengemukakan bahwa model pembelajaran kooperatif think talk write merupakan model pembelajaran yang dapat membawa siswa untuk aktif berpikir, berbicara, dan menulis. Selanjutnya, Minarsih dan Putra (2020:37)

Silampari Bisa: Jurnal Penelitian Pendidikan Bahasa Indonesia, Daerah, dan Asing Vol. 4, No. 2, 2021 
mengemukakan bahwa model pembelajaran kooperatif think talk write merupakan model pembelajaran yang menitikberatkan pada proses berpikir, berbicara, dan menulis, sehingga dalam proses pembelajaran hal yang dipikirkan oleh siswa dapat disampaikan dengan perencanaan yang baik. Huda (2019:218) mengemukakan bahwa model pembelajaran kooperatif think talk write merupakan model pembelajaran yang dapat digunakan sebagai sarana untuk melatih keterampilan berbahasa secara lisan dan secara tulis. Selanjutnya, Erina dkk., (2018:7) mengemukakan bahwa, model pembelajaran kooperatif think talk write dapat diartikan sebagai model pembelajaran yang komunikatif dalam suatu bacaan yang dilakukan dengan menyeluruh dan kemudian disusun dalam suatu bagian yang dianggap penting. Hal ini juga sejalan dengan pendapat Huda (2019:215) mengatakan bahwa model pembelajaran kooperatif think talk write merupakan model pembelajaran dengan pendekatan komunikatif, karena dalam menerapkan model pembelajaran kooperatif think talk write tidak hanya menuntut siswa untuk dapat membaca dan menulis dengan baik, tetapi model pembelajaran kooperatif think talk write juga dapat menuntut siswa untuk dapat belajar dan menerima informasi dari siapapun, serta siswa dapat menjadi fasilitator untuk menyampaikan informasi kepada sesama siswa. Dalam penerapan model pembelajaran kooperatif think talk write, selain untuk menambah pengetahuan dan keterampilan peserta didik, model pembelajaran ini juga dapat membantu mengembangkan sikap dan perilaku peserta didik untuk berinteraksi antara sesama siswa, berinteraksi antara siswa dan guru, serta berinteraksi antara siswa dan sumber belajar.

Huda (2019:218) mengemukakan bahwa terdapat tiga tahapan dalam menerapkan model pembelajaran kooperatif think talk write yaitu tahapan berpikir (think) yang dapat ditemukan dari proses membaca suatu teks, kemudian membuat catatan-catatan kecil mengenai ide yang telah diperoleh dari teks yang telah dibaca, serta siswa dapat memikirkan langkah-langkah dalam menyelesaikan tugas yang diberikan, tahapan berbicara (talk) merupakan kesempatan bagi siswa untuk mengemukakan hasil tugas yang telah diperoleh pada tahapan berpikir (think), dan tahapan menulis (write) dapat ditemukan pada saat siswa menuliskan ide yang telah diperoleh dari tahapan berpikir (think) dan tahap berbicara (talk). Mesterianti dkk., (2019:102) juga memaparkan tiga tahap yang dapat digunakan dalam menerapkan model pembelajaran kooperatif think talk write diantaranya yaitu: pertama, tahap berpikir (think), pada tahap ini peserta didik secara individu memikirkan strategi dalam menyelesaikan masalah, dan peserta didik dapat membuat catatan kecil mengenai ide yang telah diperoleh dari suatu bacaan dan menulis hal-hal yang tidak dipahami dari bacaan tersebut. Kedua, tahap berbicara (talk), pada tahap ini peserta didik diberikan kesempatan untuk mengemukakan hal yang telah diperoleh dari hasil bacaan dalam kegiatan diskusi kelompok. Ketiga, menulis (write), pada tahap ini peserta didik dapat menulis hasil pemikiran yang telah diperoleh dari kegiatan membaca dan berdiskusi dalam menyelesaikan suatu masalah.

Pada tahapan berpikir (think) terjadi suatu proses pembelajaran untuk mendapatkan pengetahuan yang diperoleh dari kegiatan membaca dan kegiatan mencatat bahan bacaan. Menurut Wiederhold (dalam Yamin dan Ansari 2012:85) mengemukakan bahwa keterampilan membaca secara komprehensif dapat dianggap sebagai kegiatan berpikir karena kegiatan membaca dapat meliputi keterampilan siswa dalam membaca baris demi baris bahan bacaan dan kegiatan membaca yang dianggap penting. Selanjutnya, proses mencatat merupakan suatu kegiatan dalam 
menyelidiki tujuan yang terdapat dalam teks bacaan dan menyelidiki bahan bacaan yang ditulis (Wiederhold dalam Yamin dan Ansari, 2012:85). Kegiatan belajar dengan proses membaca dan membuat catatan merupakan suatu proses berpikir sebelum membuat catatan dan proses berpikir selama membuat catatan.

Pada tahapan berbicara (talk) terjadi suatu proses kegiatan pembelajaran untuk menumbuhkan keterampilan siswa dalam aktivitas berbicara. Hamdayama (2014:218) mengemukakan bahwa kegiatan berbicara merupakan suatu sarana bagi siswa untuk mengungkapkan dan merefleksi pikiran siswa dengan menggunakan bahasa yang mereka pahami. Dalam tahapan berbicara (talk) dapat memungkinkan siswa untuk melakukan diskusi dengan membagi siswa menjadi beberapa kelompok dengan jumlah setiap kelompok 3-5 siswa (Erina dkk, 2018:7). Hal ini sejalan dengan pendapat Yamin dan Ansari (2012:87) yang mengemukakan bahwa keterampilan berbicara sesama siswa maupun dengan guru dapat mempercepat kemampuan siswa untuk mengemukakan ide dan gagasannya dalam bentuk tulisan.

Pada tahapan menulis (write) terjadi suatu proses mengkontruksikan ide yang telah diperoleh dari kegiatan berpikir (think) dan kegiatan berbicara (talk). Huda (2019:219) mengemukakan bahwa tulisan yang ditulis oleh siswa merupakan tulisan yang terdiri atas landasan konsep yang digunakan, keterkaitan dengan materi sebelumnya, dan cara untuk menyelesaikan masalah. Kegiatan menulis dapat membantu siswa untuk menghubungkan hasil pengetahuan yang telah diperoleh dari tahapan berpikir (think) dan tahapan berbicara (talk), dan dapat memberikan kesempatan bagi guru untuk dapat mengetahui perkembangan pemahaman siswa mengenai materi pembelajaran yang sudah dilakukan (Yamin dan Ansari, 2012:87; Noermanzah dkk., 2018:221).

Model pembelajaran kooperatif think talk write sudah banyak diteliti di berbagai tempat dalam memperbaiki hasil pembelajaran keterampilan berbahasa, misalnya model pembelajaran kooperatif think talk write yang diterapkan oleh Mulyani dan Syahrul (2019:380) yang berguna untuk melihat pengaruh model pembelajaran kooperatif think talk write dalam meningkatkan keterampilan menulis teks persuasi pada peserta didik. Selanjutnya, Putri dan Syahrul (2019:70) yang berguna untuk melihat pengaruh model pembelajaran kooperatif think talk write dalam keterampilan menulis teks fabel. Dari kedua penelitian yang telah dipaparkan, terdapat persamaan model pembelajaran yang diterapkan dalam penelitian ini, yaitu menggunakan model pembelajaran kooperatif think talk write sebagai model pembelajaran yang dapat digunakan dalam kegiatan pembelajaran. Tetapi, terdapat beberapa perbedaan yang akan dilakukan oleh di dalam penelitian ini. Pada penelitian ini, peneliti akan memaparkan dan mengkaji penerapan model pembelajaran kooperatif think talk write dalam pembelajaran menulis surat pribadi.

Surat pribadi adalah sebuah tulisan pribadi yang berguna untuk menyatakan halhal yang berasal dari gagasan atau perasaan kita tentang pengalaman kita yang diwujudkan dalam bentuk tulisan, baik bagi kebahagian sendiri atau bagi keperluan dan kesenangan keluarga atau sahabat (Tarigan, 2013:32). Kosasih (2019:97) mengatakan bahwa, surat pribadi merupakan surat yang ditulis secara pribadi dan berfungsi untuk disampaikan kepada seseorang atau kepada suatu lembaga. Sejalan dengan pendapat tersebut, Semi (2007:13) juga mengatakan bahwa surat pribadi merupakan surat yang memuat hal-hal yang berkaitan dengan persoalan pribadi yang dikirim oleh seseorang untuk ditujukan kepada keluarga, sahabat, atau orang yang

Silampari Bisa: Jurnal Penelitian Pendidikan Bahasa Indonesia, Daerah, dan Asing Vol. 4, No. 2, 2021 
sudah diketahui memiliki sifat yang baik secara pribadi. Selanjutnya, Zuhriandini (2020:42) mengemukakan bahwa, surat pribadi adalah alat komunikasi antara satu orang dengan orang lain atau satu instansi dengan instansi lain yang tujuannya untuk menyampaikan pesan atau informasi dengan menggunakan tulisan. Surat yang ditulis bukan hanya sebagai kegiatan dalam menyampaikan pesan untuk kepentingan tidak resmi, tetapi surat juga digunakan sebagai alat dalam menyampaikan pesan untuk kepentingan resmi. Dalam menulis surat pribadi terdapat beberapa hal yang harus diperhatikan agar surat yang ditulis dapat tersampaikan dengan baik kepada pembaca, yaitu penulis harus mengetahui struktur dalam menulis surat pribadi, penulis dapat memfokuskan isi dan tujuan dalam menulis surat pribadi, dan penulis dapat menggunakan kaidah kebahasaan yang tepat dalam menulis surat pribadi.

Hasil observasi dan wawancara dengan guru bahasa Indonesia di SMP Pelita Kasih Kota Bengkulu menunjukkan bahwa kemampuan menulis surat pribadi siswa masih rendah terlihat dari nilai rata-rata siswa baru mencapai 71,00 dari nilai KKM sebesar 70,00. Dengan menerapkan model pembelajaran kooperatif think talk write (ttw) dalam proses pembelajaran menulis surat pribadi diharapkan bahwa hasil kemampuan siswa dalam menulis surat pribadi menghasilkan nilai rata-rata lebih baik lagi. Berdasarkan latar belakang tersebut, penulis tertarik untuk menjawab masalah mengenai: 1) Bagaimanakah penerapan model pembelajaran kooperatif think talk write dalam pembelajaran menulis surat pribadi?; dan 2) Bagaimanakah hasil yang diperoleh dari penerapan model pembelajaran kooperatif think talk write pada siswa kelas VII SMP Pelita Kasih Kota Bengkulu? Tujuannya untuk mendeskripsikan penerapan model pembelajaran kooperatif think talk write dalam pembelajaran menulis surat pribadi dan mendeskripsikan hasil yang diperoleh dari penerapan model pembelajaran kooperatif think talk write pada siswa kelas VII SMP Pelita Kasih Kota Bengkulu.

\section{B. Metode Penelitian}

Metode yang digunakan dalam penelitian ini adalah metode deskriptif dengan pendekatan kualitatif. Tujuan penulis menggunakan metode deskriptif kualitatif, yaitu untuk mendeskripsikan kegiatan guru dan siswa dalam menerapkan model pembelajaran kooperatif think talk write, dan mendeskripsikan hasil belajar siswa setelah menerima model pembelajaran kooperatif think talk write pada pembelajaran menulis surat pribadi. Data dalam penelitian ini berupa aktivitas pembelajaran, ujaran, dan hasil pembelajaran. Sedangkan sumber data berupa aktivitas yang dilakukan oleh guru dalam menerapkan model pembelajaran kooperatif think talk write, aktivitas siswa dalam mengikuti pembelajaran dengan diterapkannya model pembelajaran kooperatif think talk write, dan hasil belajar menulis surat pribadi. Subjek yang digunakan dalam penelitian ini adalah seluruh siswa kelas VII (Tujuh) SMP Pelita Kasih Kota Bengkulu semester genap tahun 2021/2022 yang berjumlah 24 siswa, dengan jumlah 9 siswa perempuan dan 15 jumlah laki-laki.

Teknik pengumpulan data menggunakan observasi dan dokumentasi. Teknik pengumpulan data dengan menggunakan observasi karena penulis bertujuan melakukan observasi secara langsung mengenai aktivitas yang dilakukan oleh guru dan aktivitas yang dilakukan oleh siswa dengan menerapkan model pembelajaran kooperatif think talk write. Teknik pengumpulan data dengan menggunakan dokumentasi dalam penelitian yaitu untuk mengumpulkan data berupa foto kegiatan guru dan siswa selama proses pembelajaran menulis surat pribadi dengan model

Silampari Bisa: Jurnal Penelitian Pendidikan Bahasa Indonesia, Daerah, dan Asing Vol. 4, No. 2, 2021 


\section{Marinir Tu Meilani Simanjuntak, Arono, Noermanzah}

Penerapan Model Pembelajaran Kooperatif Think Talk Write (TTW) dalam Pembelajaran Menulis Surat Pribadi pada Siswa Kelas VII SMP Pelita Kasih Kota Bengkulu

pembelajaran kooperatif think talk write, dan dokumentasi berupa hasil tes kemampuan menulis surat pribadi. Instrumen yang digunakan dalam penelitian ini yaitu menggunakan instrument observasi mengenai penerapan model pembelajaran kooperatif think talk write bagi guru dan bagi siswa, dan instrumen dokumentasi berupa foto kegiatan dan tes menulis surat pribadi. Untuk kisi-kisi kemampuan menulis surat pribadi dapat dilihat pada tabel berikut.

Tabel 1. Kisi-kisi Kemapuan Menulis Surat Pribadi

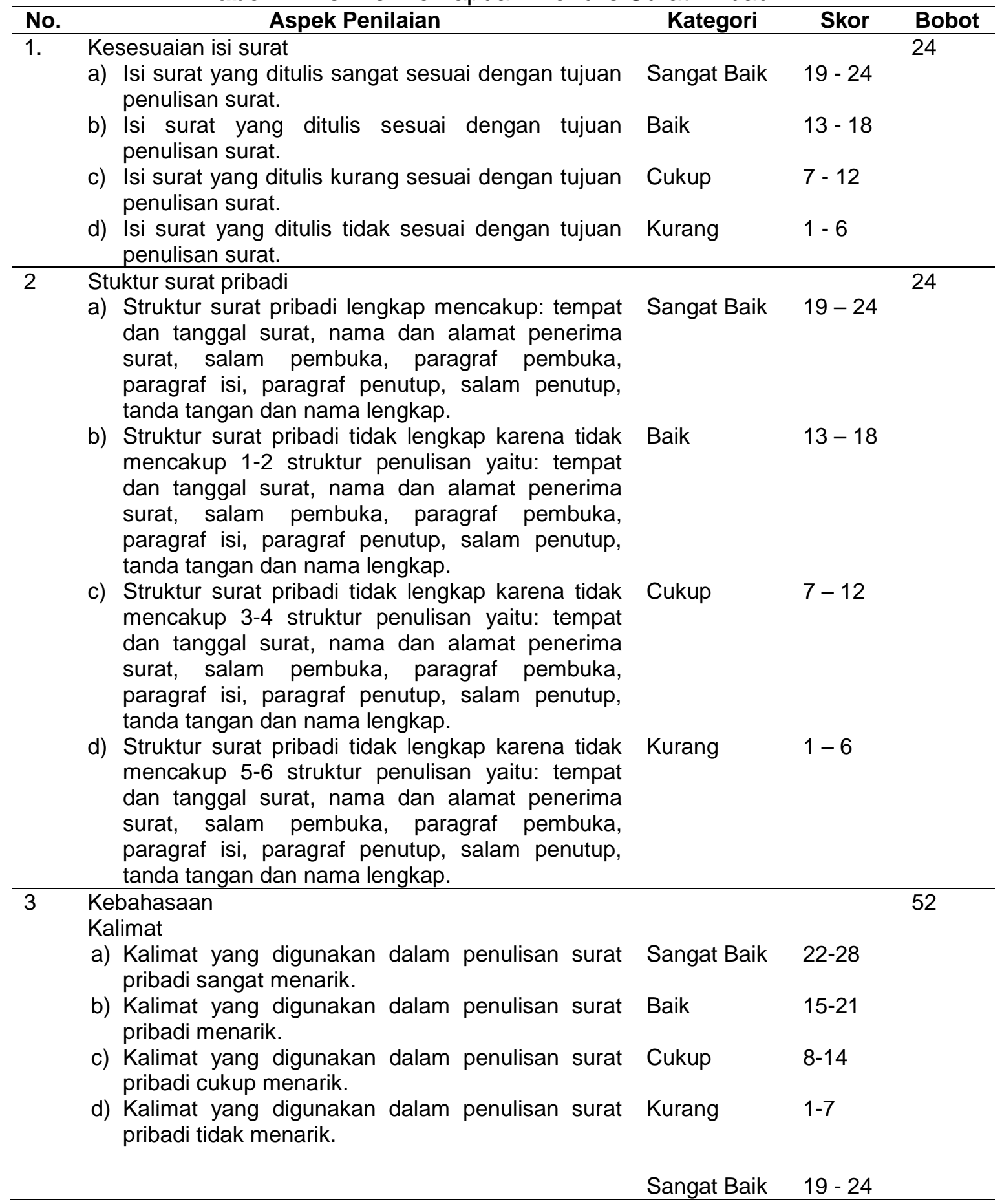

Silampari Bisa: Jurnal Penelitian Pendidikan Bahasa Indonesia, Daerah, dan Asing Vol. 4, No. 2, 2021 


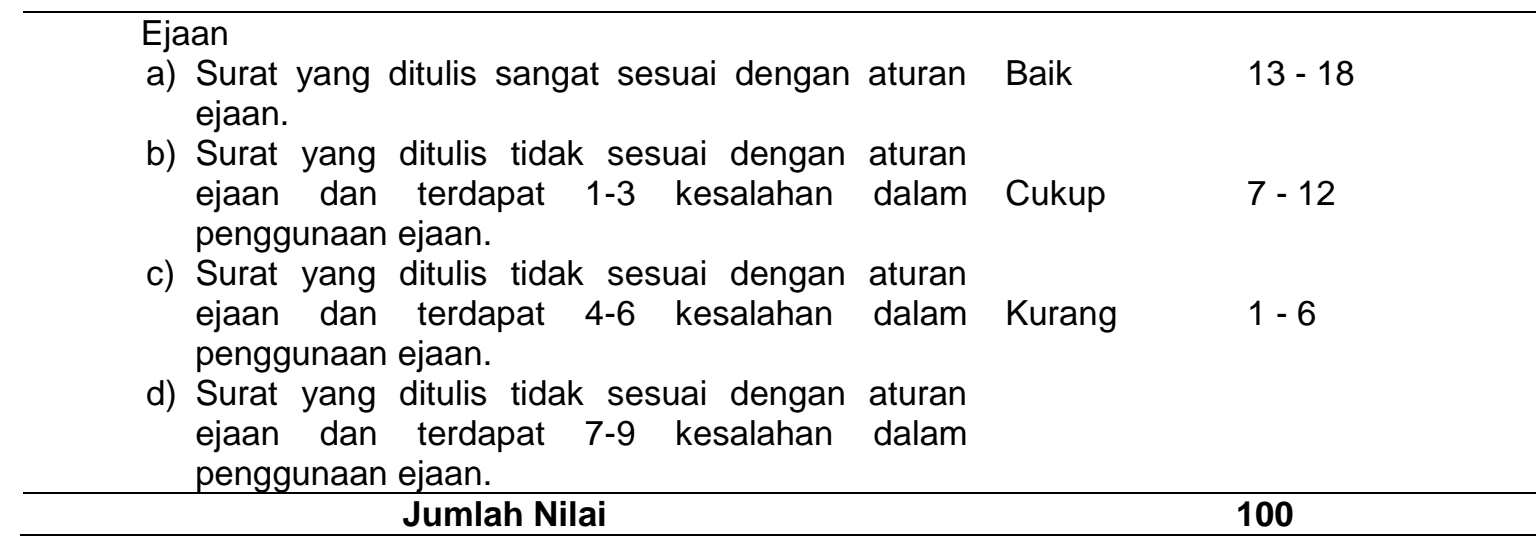

Teknik analisis data yang digunakan dengan langkah-langkah berikut: 1) Reduksi data, hasil data yang diperoleh dari lapangan akan difokuskan pada data dari hasil observasi, dan data hasil dokumentasi berupa foto kegiatan dan hasil tes kemampuan menulis surat pribadi. 2) Menyajikan data, penyajian data dalam penelitian kualitatif dapat dilakukan dengan menyajikan data hasil observasi penerapan model pembelajaran kooperatif think talk write, dan dokumentasi yang berupa foto kegiatan dan hasil tes menulis surat pribadi. 3) Penarikan Kesimpulan/Verifikasi (Conclucion Drawing/Verification), penarikan kesimpulan dalam penelitian ini dilakukan dengan dua tahap, yaitu yang pertama peneliti akan menyusun simpulan sementara, tetapi dengan bertambahnya data maka perlu dilakukannya verifikasi yaitu dengan cara mempelajari kembali data-data yang ada. Kedua, menarik simpulan akhir setelah kegiatan pertama selesai. Penarikan kesimpulan dilakukan dengan membandingkan kesesuaian hasil observasi yang dilakukan peneliti secara berulang-ulang.

Uji keabsahan data dalam penelitian ini dilakukan dengan menggunakan inter rater dan member check. Inter rater digunakan oleh peneliti yaitu untuk melihat dan menguji persamaan nilai yang diperoleh antara penilai satu dengan penilai dua. Kemudian, Member check merupakan sutau proses untuk melakukan pengecekan kembali mengenai data yang telah diperoleh peneliti dengan mengecek kembali kepada pemberi data (Sugiyono, 2016:375). Member check dalam penelitian ini menyajikan seluruh data hasil observasi dan data hasil dokumen penilaian.

\section{Hasil Penelitian dan pembahasan}

1. Hasil Penelitian

a. Penerapan Model Pembelajaran Kooperatif Think Talk Write

Penelitian ini dilakukan dalam dua kali pertemuan. Berikut penjelasan yang lebih rinci mengenai hasil yang ditemukan peneliti selama proses pembelajaran menulis surat:

\section{1) Pertemuan Pertama}

Terdapat tiga tahapan yang dilakukan selama diterapkannya model pembelajaran kooperatif think talk write sebagai berikut:

a) Tahap Berpikir (Think)

Pada tahapan berpikir (think) dalam kegiatan mengamati, terlebih dahulu guru memberikan bahan bacaan dan tugas kepada siswa. Bahan bacaan yang diberikan guru berupa bahan bacaan yang berisi bagian-bagian struktur surat pribadi. Selanjutnya, guru memberikan intruksi atau perintah kepada siswa untuk mengisi 


\section{Marinir Tu Meilani Simanjuntak, Arono, Noermanzah}

Penerapan Model Pembelajaran Kooperatif Think Talk Write (TTW) dalam Pembelajaran Menulis Surat Pribadi pada Siswa Kelas VII SMP Pelita Kasih Kota Bengkulu

surat pribadi yang masih rumpang dengan memperhatikan struktur surat pribadi yang terdapat dalam bahan bacaan yang telah dibagikan. Pada kegiatan menanya, terdapat beberapa siswa yang masih belum memahami cara untuk melengkapi surat pribadi, sehingga siswa menanyakan hal tersebut kepada guru. Setelah siswa mendapatkan jawaban dari guru dan telah memahami cara untuk melengkapi struktur surat pribadi. Kemudian, siswa menggali informasi mengenai struktur surat pribadi yang terdapat dalam bahan bacaan dan siswa membuat tabel struktur surat pribadi, hal ini dilakukan untuk memudahkan siswa dalam memahami dan mengisi surat pribadi yang masih rumpang.

Setelah siswa menyelesaikan tugas yang diberikan oleh guru, selanjutnya siswa akan membawa hasil dari tahapan berpikir (think) yang terdapat dalam kegiatan mengamati, kegiatan menanya, dan kegiatan mengumpulkan informasi ke dalam bentuk diskusi yang termasuk dalam tahapan berbicara (talk).

\section{b) Tahap Berbicara (Talk)}

Langkah pembelajaran yang dilakukan selanjutnya yaitu masuk pada tahap berbicara (talk), tahap ini termasuk dalam kegiatan mengasosiasi. Dalam melakukan tahapan berbicara (talk) dalam bentuk diskusi, guru membimbing siswa untuk melakukan diskusi dengan tidak merubah posisi tempat duduk siswa, sehingga siswa tidak dibentuk menjadi beberapa kelompok. Hal ini dilakukan oleh guru karena proses pembelajaran yang dilakukan selama penelitian sedang terjadi pandemi covid-19, dan siswa diarahkan untuk tetap menjaga jarak satu dengan yang lainnya, serta siswa dihimbau untuk tetap menggunakan protokol kesehatan.

Pada tahapan berbicara (talk), langkah yang dilakukan oleh guru yaitu dengan menunjuk dan menanyakan kepada beberapa siswa mengenai hasil catatan yang telah diperoleh berupa tabel struktur surat pribadi. Guru meminta siswa untuk membacakan hasil catatannya di tempat duduk masing-masing, kemudian guru menghimbau siswa untuk saling bertanya jawab mengenai hasil catatan siswa dan meminta siswa untuk saling melengkapi hasil catatan mengenai struktur surat pribadi.

Setelah siswa dan guru mendiskusikan mengenai hasil catatan berupa tabel struktur surat pribadi, selanjutnya guru meminta siswa untuk membuka tugas yang telah diisi siswa yaitu tugas melengkapi surat pribadi yang telah diberikan oleh guru pada tahapan berpikir (think). Dalam melakukan diskusi mengenai surat pribadi yang telah dilengkapi oleh siswa, guru meminta beberapa siswa untuk mengemukakan jawabannya dan meminta beberapa alasan siswa mengenai hasil jawabannya. Hal ini ini dilakukan, agar siswa lebih memahami dan tidak hanya sekedar membuat tugas, tetapi siswa mendapatkan pembelajaran yang lebih bermakna.

Pada tahapan berbicara (talk) dalam bentuk diskusi yang dipandu oleh guru, terdapat beberapa siswa yang mengalami kesulitan dalam mengemukakan hasil catatannya, sehingga guru memberikan dorongan berupa motivasi kepada siswa untuk berani tampil berbicara dalam bentuk diskusi dan aktif dalam proses kegiatan pembelajaran. Selama proses pembelajaran pada tahapan berbicara (talk) dalam bentuk diskusi, guru tidak hanya fokus pada siswa yang memiliki kemampuan yang lebih dan siswa yang aktif selama proses pembelajaran, tetapi guru juga memperhatikan beberapa siswa yang tidak aktif dalam berdiskusi dan siswa yang tidak memperhatikan saat siswa lain sedang berbicara, sehingga guru memanggil dan menunjuk siswa yang tidak aktif dalam proses pembelajaran untuk ikut berpartisipasi

Silampari Bisa: Jurnal Penelitian Pendidikan Bahasa Indonesia, Daerah, dan Asing Vol. 4, No. 2, 2021 
dalam mendiskusikan hasil catatan dan tugas yang telah dikerjakan. Diskusi yang dilakukan pada pertemuan pertama terdapat dua sesi diskusi, pada sesi pertama diskusi dilakukan dengan membahas hasil catatan siswa dan tabel struktur surat pribadi yang telah ditulis oleh siswa dari bahan bacaan yang diberikan oleh guru. Pada sesi kedua, diskusi yang dilakukan yaitu membahas mengenai hasil pekerjaan siswa mengenai kelengkapan struktur surat pribadi yang telah dikerjakan oleh siswa.

Setelah siswa selesai mendiskusikan hasil catatan struktur surat pribadi dan mendiskusikan mengenai hasil jawaban dalam surat pribadi yang belum lengkap. Langkah selanjutnya yang dilakukan oleh guru, yaitu memberikan apresiasi kepada siswa yang sudah berani untuk tampil berbicara dan siswa yang sudah berani utuk memberikan pertanyaannya kepada sesama temannya mengenai hal yang belum dipahami oleh siswa, sehingga terjadi suatu interaksi antara siswa untuk saling bertanya dan memberikan jawaban dari hasil catatan yang telah diperoleh siswa.

\section{c) Tahap Menulis (Write)}

Proses pembelajaran selanjutnya yang dilakukan oleh guru yaitu masuk pada tahapan menulis (write), langkah pembelajaran yang terdapat dalam tahapan menulis (write) yaitu langkah pembelajaran yang termasuk dalam kegiatan mengomunikasikan. Tahapan ini dilakukan oleh guru setelah proses pembelajaran yang telah dilalui pada tahapan berpikir (think) dan tahapan berbicara (talk). Sebelum guru membagikan tugas kepada siswa, terlebih dahulu guru menjelaskan kembali mengenai struktur surat pribadi dan letak struktur surat pribadi, hal ini dilakukan agar siswa dapat lebih memahami materi mengenai struktur surat pribadi dan siswa dapat mengingat struktur surat pribadi dalam jangka panjang karena dipelajari secara berulang-ulang.

Setelah guru menjelaskan mengenai struktur surat pribadi, selanjutnya guru membagikan tugas kepada masing-masing siswa, dan memberikan petunjuk kepada siswa untuk membaca dan menyusun tugas yang telah dibagikan guru yang berupa surat pribadi yang masih teracak. Guru meminta siswa untuk menuliskan hasil susunan surat pribadi ke dalam buku tugas siswa. Hal ini dilakukan oleh guru, agar siswa dapat mengontruksikan hasil belajar yang telah diperoleh dari tahapan berpikir (think) dan tahapan berbicara (talk), agar siswa dapat lebih memahami dan menerapkan hasil belajarnya dalam bentuk kegiatan yang nyata.

Selama proses pembelajaran pada tahapan menulis (write), guru selalu membimbing siswa untuk dapat berlatih dalam menyusun surat pribadi, guru juga bertanya kepada siswa yang merasa kesulitan dalam menyusun surat pribadi untuk maju ke meja guru. Terdapat beberapa siswa yang belum memahami cara dalam menyusun surat pribadi dan siswa secara langsung maju ke meja guru dan membawa tugasnya, kemudian guru langsung membimbing siswa untuk mengerjakan tugasnya dengan memberikan penjelasan yang lebih mendalam mengenai struktur surat pribadi, guru juga memberikan beberapa pertanyaan kepada siswa mengenai urutan struktur surat pribadi yang terdapat dalam bahan bacaan, sehingga siswa dapat lebih memahami mengenai struktur surat pribadi. Setelah siswa selesai dalam menyusun surat pribadi dengan memperhatikan struktur surat pribadi yang benar. Kemudian, guru meminta siswa yang telah menyelesaikan tugasnya untuk mengumpulkan tugas tersebut ke meja guru. 


\section{2) Pertemuan Kedua}

Pada pertemuan kedua, guru menerapkan tiga tahapan model pembelajaran kooperatif think talk write sebagai berikut:

a) Tahap Berpikir ( Think)

Pada tahapan berpikir (think) dalam kegiatan mengamati, langkah pembelajaran yang dilakukan oleh guru yaitu membagikan bahan bacaan kepada siswa yang di dalamnya terdapat contoh surat pribadi, dan guru juga memberikan intruksi atau perintah kepada siswa untuk mengamati dan menelaah kalimat dan ejaan yang terdapat dalam contoh surat pribadi yang telah dibagikan oleh guru.

Setelah siswa membaca surat pribadi yang telah dibagikan oleh guru, langkah pembelajaran selanjutnya masuk pada kegiatan menanya. Proses pembelajaran pada kegiatan menanya sangat memerlukan keterampilan guru untuk meminta siswa dalam mengajukan pertanyaan mengenai bahan bacaan yang telah dibagikan oleh guru, sehingga dapat terlihat proses berpikir dari siswa mengenai bahan bacaan yang telah dibaca oleh siswa secara sekilas. Pada kegiatan menanya, terlebih dahulu guru memberikan pertanyaan kepada siswa mengenai hal yang tidak dipahami dari bahan bacaan berupa contoh surat pribadi yang telah diberikan oleh guru, dan terdapat beberapa siswa yang mengangkat tangan untuk mengemukakan pertanyaannya mengenai cara dalam menelaah surat pribadi tersebut.

Setelah siswa mengajukan pertanyaan, kemudian guru menjelaskan secara lebih mendalam kepada seluruh siswa mengenai cara menelaah kaidah kebahasaan surat pribadi, dan guru memberikan tambahan informasi kepada siswa dengan mengarahkan pembelajaran masuk pada kegiatan mengumpulkan informasi. Pada kegiatan mengumpulkan informasi, guru meminta siswa untuk menggali informasi dari bahan bacaan yang telah diberikan, serta guru meminta siswa untuk membuat catatan mengenai kaidah kebahasaan surat pribadi yang terdapat dalam bahan bacaan yang dibagikan seperti langkah pembelajaran yang telah dilakukan pada pertemuan pertama. Guru juga memberikan satu contoh mengenai kaidah kebahasaan yang terdapat dalam contoh surat pribadi, sehingga siswa mendapatkan tambahan informasi yang lebih lengkap mengenai cara dalam menelaah kebahasaan surat pribadi.

Setelah kegiatan mengamati, kegiatan menanya, dan kegiatan mengumpulkan informasi telah dilaksanakan sebagai tahapan berpikir (think), langkah pembelajaran selanjutnya yaitu masuk pada tahapan berbicara (talk).

\section{b) Tahap Berbicara ( Talk)}

Tahapan berbicara (talk) terdapat dalam kegiatan mengasosiasi. Pada pertemuan kedua dalam tahapan berbicara (talk), diskusi yang dilakukan sama seperti diskusi yang telah dilakukan pada pertemuan pertama. Pada tahapan berbicara (talk) dalam bentuk diskusi, guru selalu memandu dan membimbing siswa untuk melakukan diskusi dengan tidak merubah posisi tempat duduk siswa. Pada proses pembelajaran dalam tahapan berbicara (talk) pada pertemuan kedua, terlebih dahulu guru memotivasi dan meminta siswa untuk berani tampil dalam mengemukakan hasil tugas yang telah dikerjakan oleh siswa. Pada tahapan berbicara (talk) terdapat beberapa siswa yang berani mengangkat tangan untuk mengemukakan hasil tugas yang telah dikerjakan, dan terdapat beberapa siswa yang berani untuk mengajukan pertanyaan

Silampari Bisa: Jurnal Penelitian Pendidikan Bahasa Indonesia, Daerah, dan Asing Vol. 4, No. 2, 2021 
bahkan berani untuk menambahkan pendapatnya mengenai tugas yang telah dikerjakan.

Pada tahapan berbicara (talk) merupakan tahapan yang sulit untuk dilakukan oleh guru karena tidak semua siswa berani untuk tampil berbicara, tetapi guru selalu memberikan motivasi bahkan memberikan pertanyaan atau menunjuk siswa yang jarang berbicara untuk berani mengemukakan hasil catatannya, sehingga dengan motivasi dan bimbingan dari guru dapat mengaktifkan siswa untuk ikut berproses dalam kegiatan pembelajaran.

Tahapan berbicara (talk) pada pertemuan kedua sedikit mengalami perbedaan dengan tahapan berbicara (talk) yang telah dilakukan pada pertemuan pertama. Bentuk diskusi yang dilakukan oleh guru pada pertemuan kedua, yaitu guru tidak membedakan atau membagi diskusi menjadi beberapa sesi. Tetapi, guru langsung meminta siswa yang telah mengangkat tangan untuk membacakan hasil catatan dan tugas yang telah dikerjakan pada tahapan berpikir (think). Guru juga membimbing siswa dalam melakukan diskusi, dan guru memperhatikan setiap siswa yang kurang aktif dalam berdiskusi, sehingga guru akan menunjuk siswa secara langsung untuk memberikan pertanyaan, mengemukakan pendapatnya, atau membacakan hasil catatan dan tugas yang telah dikerjakan oleh siswa.

Selama proses pembelajaran pada tahapan berbicara (talk), guru tidak pernah menyalahkan catatan atau tugas siswa secara terang-terangan, tetapi guru selalu membimbing siswa dan mengarahkan diskusi untuk mencapai tujuan pembelajaran yang diinginkan. Setelah proses diskusi selesai, guru selalu memberikan apresiasi dan motivasi kepada siswa karena sudah berani untuk tampil berbicara. Kemudian, guru memberikan penjelasan tambahan kepada siswa mengenai kaidah kebahasaan surat pribadi, sehingga siswa tidak hanya belajar dari hasil catatannya saja dan hasil diskusi dari teman-temannya, tetapi siswa juga lebih memahami materi kebahasaan surat pribadi yang disampaikan oleh guru.

\section{c) Tahap Menulis (Write)}

Pada pertemuan kedua dalam tahapan menulis (write), guru meminta siswa untuk mengkontruksikan pengetahuan yang telah diperoleh selama proses pembelajaran surat pribadi. Pada tahapan menulis (write), guru meminta siswa untuk membuat satu surat pribadi berdasarkan tujuan pengiriman yang telah ditentukan. Sebelum siswa menulis surat pribadi, terlebih dahulu guru memberikan ilustrasi atau petunjuk kepada siswa untuk menulis surat pribadi sesuai dengan arahan guru. Guru memberikan ilustrasi kepada siswa untuk menulis surat pribadi dalam rangka meminta uang kepada Nenek dan Kakak untuk membeli baju baru. Ilustrasi yang diberikan oleh guru kepada siswa berupa meminta uang untuk membeli baju baru, karena proses pembelajaran keterampilan menulis surat pribadi dilakukan pada saat mendekati hari raya Idul Fitri, sehingga guru meminta siswa untuk menulis surat pribadi yang ditujukan kepada Kakak dan Nenek. Keterampilan menulis surat pribadi berdasarkan ilustrasi yang diberikan oleh guru merupakan bentuk pembelajaran yang nyata dan bermakna bagi siswa, dan dapat diterapkan oleh siswa apabila siswa ingin meminta sesuatu kepada keluarga yang berada jauh dari siswa.

Setelah beberapa siswa selesai menulis surat pribadi dan mengumpulkan surat pribadi yang telah ditulis ke meja guru. Kemudian, guru langsung membaca dan mengoreksi kalimat yang digunakan siswa dalam menulis surat pribadi. Terdapat beberapa surat pribadi siswa yang ditulis oleh siswa dengan menggunakan kalimat 
Marinir Tu Meilani Simanjuntak, Arono, Noermanzah

Penerapan Model Pembelajaran Kooperatif Think Talk Write (TTW) dalam Pembelajaran Menulis Surat Pribadi pada Siswa Kelas VII SMP Pelita Kasih Kota Bengkulu

yang kurang tepat yang terdapat dalam paragraf penutup, sehingga guru memanggil siswa untuk datang ke meja guru dan guru memberikan beberapa masukan mengenai kalimat yang kurang tepat.

\section{b. Hasil Kemampuan Menulis Surat Pribadi yang diperoleh dari Penerapan Model Pembelajaran Kooperatif Think Talk Write}

Hasil kemampuan menulis surat pribadi yang diperoleh dari penerapan model pembelajaran kooperatif think talk write siswa kelas VII SMP Pelita Kasih Kota Bengkulu yang dilakukan dalam kegiatan pembelajaran pada pertemuan kedua. Berdasarkan keterampilan siswa dalam menulis surat pribadi, maka siswa memperoleh hasil pada semua aspek penilaian yaitu penilaian aspek isi (X1), penilaian aspek struktur (X2), dan penilaian aspek kaidah kebahasaan (X3) sebagai berikut:

Tabel 2. Hasil Kemampuan Menulis Surat Pribadi siswa kelas VII SMP Pelita Kasih Kota Bengkulu

\begin{tabular}{|c|c|c|c|c|c|c|c|}
\hline No. & $\begin{array}{l}\text { Kode } \\
\text { Sampel }\end{array}$ & $\begin{array}{c}\mathbf{X 1} \\
(\mathrm{P} 1+\mathrm{P2}) \\
\frac{2}{2}\end{array}$ & $\begin{array}{c}\mathrm{X} 2 \\
(\mathrm{P} 1+\mathrm{P} 2) \\
2\end{array}$ & $\begin{array}{c}\mathrm{X3} \\
(\mathrm{P} 1+\mathrm{P} 2) \\
\frac{2}{2}\end{array}$ & $\begin{array}{l}\text { Total } \\
\text { Skor }\end{array}$ & Kategori & Keterangan \\
\hline 1. & A & 22 & 12 & 30 & 64 & Cukup & BT \\
\hline 2. & AAS & 23 & 12 & 33,5 & 68,5 & Cukup & BT \\
\hline 3. & $\mathrm{Bi}$ & 24 & 16,5 & 33,5 & 74 & Cukup & $\mathrm{T}$ \\
\hline 4. & $\mathrm{Ba}$ & 23 & 12 & 30 & 65 & Cukup & BT \\
\hline 5. & DP & 10 & 13 & 22 & 45 & Kurang & BT \\
\hline 6. & FJ & 21 & 21 & 38 & 80 & Baik & $\mathrm{T}$ \\
\hline 7. & FTJ & 24 & 24 & 34,5 & 82,5 & Baik & $T$ \\
\hline 8. & $\mathrm{Gl}$ & 24 & 24 & 34 & 82 & Baik & $T$ \\
\hline 9. & $\mathrm{HP}$ & 24 & 24 & 39,5 & 87,5 & $\begin{array}{l}\text { Sangat } \\
\text { Baik }\end{array}$ & $\mathrm{T}$ \\
\hline 10. & IP & 24 & 19 & 39 & 82 & Baik & $T$ \\
\hline 11. & J & 24 & 24 & 40 & 88 & $\begin{array}{l}\text { Sangat } \\
\text { Baik }\end{array}$ & $T$ \\
\hline 12. & $\mathrm{Je}$ & 22 & 20 & 32,5 & 74,5 & Cukup & $T$ \\
\hline 13. & JAC & 24 & 24 & 36,5 & 84,5 & Baik & $T$ \\
\hline 14. & JB & 22 & 24 & 35 & 81 & Baik & $\mathrm{T}$ \\
\hline 15. & $\mathrm{Ja}$ & 12 & 7 & 34,5 & 53,5 & Kurang & BT \\
\hline 16. & $\mathrm{Ka}$ & 23 & 20 & 33 & 76 & Baik & $\mathrm{T}$ \\
\hline 17. & $\mathrm{La}$ & 24 & 22,5 & 39,5 & 86 & $\begin{array}{l}\text { Sangat } \\
\text { Baik }\end{array}$ & $T$ \\
\hline 18. & Rs & 23 & 13 & 38,5 & 74,5 & Cukup & $\mathrm{T}$ \\
\hline 19. & $\mathrm{RP}$ & 24 & 24 & 31 & 79 & Baik & $T$ \\
\hline 20. & $\mathrm{RT}$ & 22 & 22 & 34,5 & 78,5 & Baik & $\mathrm{T}$ \\
\hline 21. & $\mathrm{SI}$ & 23,5 & 22 & 29,5 & 75 & Cukup & $T$ \\
\hline 22. & $\mathrm{Si}$ & 15 & 22 & 31 & 68 & Cukup & BT \\
\hline 23. & YAS & 23 & 15,5 & 34,5 & 73 & Cukup & $\mathrm{T}$ \\
\hline 24 & $\mathrm{Ya}$ & 24 & 22 & 36,5 & 82,5 & Baik & $\mathrm{T}$ \\
\hline \multicolumn{2}{|c|}{ Rata-rata } & 21,85 & 19,14 & 34,18 & 75,18 & & \\
\hline
\end{tabular}

Keterangan:
$\mathrm{X} 1$
: Kesesuaian Isi Surat
X2 : Struktur Surat
X3 : Kaidah Kebahasaan

Silampari Bisa: Jurnal Penelitian Pendidikan Bahasa Indonesia, Daerah, dan Asing Vol. 4, No. 2, 2021 
T : Tuntas

BT : Belum Tuntas

Berdasarkan nilai yang telah diperoleh siswa dari hasil menulis surat pribadi berdasarkan tujuan pengiriman untuk Kakak dan Nenek. Terdapat empat kriteria kategori nilai yang diperoleh siswa, tiga siswa memperoleh nilai dengan kategori sangat baik, sepuluh siswa memperoleh nilai dengan kategori baik, sembilan siswa yang memperoleh nilai dengan kategori cukup, dan dua siswa yang memperoleh nilai dengan kategori kurang. Berdasarkan kriteria ketuntasan, terdapat enam siswa yang tidak tuntas dalam menulis surat pribadi yang nilainya masih berada di bawah Kriteria Ketuntasan Minimum (KKM), dan terdapat delapan belas siswa yang memiliki nilai tuntas dengan berpatokan pada Kriteria Ketuntasan Minimum (KKM). Persentase ketuntasan siswa dalam menulis surat pribadi dengan menggunakan perhitungan persentase diperoleh sebesar $75 \%$. Selama proses pembelajaran dalam menulis surat pribadi, terdapat beberapa skor dari aspek penilaian yang sulit untuk dibuat oleh siswa, diantaranya yaitu beberapa siswa kesulitan dalam menggunakan kaidah kebahasaan dalam surat pribadi salah satunya yaitu penulisan surat pribadi yang sesuai dengan aturan ejaan yang berlaku. Kebanyakan siswa sulit untuk membedakan kata depan dan kata awalan, dan siswa kesulitan untuk menempatkan tanda baca dalam surat pribadi yang ditulis, sehingga terdapat beberapa siswa yang menulis salam pembuka tidak menggunakan tanda baca seperti aturan penulisan surat pribadi yang berlaku, serta seluruh siswa menulis tanda tangan dan nama pengirim yang diletakkan di sebelah kiri. Hal ini dapat terjadi, karena selama proses pembelajaran guru tidak terlalu menjelaskan mengenai aturan ejaan dalam menulis surat pribadi, dan bahan bacaan yang diberikan oleh guru mengenai kaidah kebahasaan surat pribadi kurang lengkap, serta penulisan tanda tangan dan nama pengirim dalam bahan bacaan yang diberikan oleh guru terletak di sebelah kiri.

\section{Pembahasan}

Berdasarkan hasil penelitian yang telah dilakukan, maka diperoleh data mengenai penerapan model pembelajaran kooperatif think talk write yang telah dilakukan oleh guru bahasa Indonesia kelas VII SMP Pelita Kasih Kota Bengkulu, dan hasil kemampuan menulis surat pribadi yang telah diperoleh siswa dari penerapan model pembelajaran kooperatif think talk write. Tahapan pembelajaran yang dilaksanakan di dalam kelas dapat dikelompokkan menjadi tiga tahapan sesuai dengan tahapan model pembelajaran kooperatif think talk write. Menurut Huda (2019:218) dan Mesterianti dkk., (2019:102), mengemukakan bahwa terdapat tiga tahapan model pembelajaran kooperatif think talk write, antara lain (1) berpikir (think), (2) berbicara (talk), (3) menulis (write). Tetapi, terdapat beberapa perbedaaan yang dilakukan pada tahapan berbicara (talk) dan tahapan menulis (write). Tiga tahapan model pembelajaran kooperatif think talk write dijelaskan sebagai berikut.

\section{a) Tahap Berpikir (Think)}

Model pembelajaran pada tahap berpikir (think) yang terjadi pada pertemuan pertama dan kedua, yaitu proses pembelajaran dengan kegiatan guru dalam membagikan bahan bacaan dan tugas yang harus dikerjakan oleh siswa. Pada tahapan berpikir (think), siswa dituntut untuk berpikir secara kritis yang dimulai dengan kegiatan membaca secara keseluruhan dari bahan bacaan yang telah dibagikan, siswa membuat catatan dari hasil proses membaca, serta siswa dapat 


\section{Marinir Tu Meilani Simanjuntak, Arono, Noermanzah}

Penerapan Model Pembelajaran Kooperatif Think Talk Write (TTW) dalam Pembelajaran Menulis Surat Pribadi pada Siswa Kelas VII SMP Pelita Kasih Kota Bengkulu

menyelesikan tugas yang telah diberikan untuk dapat dibawa ke dalam kegiatan pembelajaran selanjutnya. Selama proses pembelajaran pada tahapan berpikir (think), terlihat bahwa siswa begitu bersemangat dan antusias dalam menerima bahan bacaan yang diberikan oleh guru, serta terdapat beberapa siswa yang mempertanyakan cara dalam mengerjakan tugas yang telah diberikan oleh guru. Kegiatan mempertanyakan cara dalam mengerjakan tugas dilakukan oleh siswa pada saat guru telah selesai dalam membagikan bahan bacaan dan guru telah selesai dalam memberikan intruksi kepada siswa, hal ini menunjukkan bahwa siswa telah masuk dalam proses berpikir.

Proses pembelajaran selama tahapan berpikir (think) yang telah dilakukan oleh guru bahasa Indonesia secara keseluruhan sesuai dengan definisi tahapan berpikir (think) menurut Huda (2019:218) dan Mesterianti dkk., (2019:102), yang mengemukakan bahwa tahapan berpikir (think) merupakan tahapan siswa dalam menerima bahan bacaan dan membuat catatan dari hasil bacaan secara individu utnuk dibawa ke dalam forum diskusi.

Proses pembelajaran pada tahapan berpikir (think) dengan memberikan bahan bacaan kepada siswa dapat mendorong rasa ingin tahu siswa untuk membaca bahan bacaan yang dibagikan oleh guru, serta siswa dapat memahami materi yang sedang dipelajari untuk memperoleh suatu pengetahuan yang baru dari hasil kegiatan membaca, sehingga terjadi suatu kegiatan berpikir bagi siswa.

\section{b) Tahap Berbicara ( Talk)}

Tahapan berbicara (talk) merupakan kegiatan pembelajaran setelah dilakukannya tahapan berpikir (think). Selama proses pembelajaran tahapan berbicara (talk) dalam bentuk diskusi pada pertemuan pertama dirasakan lebih pasif, karena siswa sibuk membaca hasil catatannya sendiri daripada memperhatikan temannya saat sedang berbicara. Siswa merasa gugup dan tidak percaya diri untuk mengemukakan hasil catatan dan hasil tugas yang telah dikerjakan, sehingga guru selalu meminta dan memanggil beberapa siswa untuk membacakan hasil tugasnya, dan guru selalu memberikan motivasi dan penguatan bagi siswa untuk berani tampil dalam berbicara.

Hasil penelitian yang diperoleh pada pertemuan pertama tidak sesuai dengan tahapan berbicara menurut Huda (2019:219) mengatakan bahwa tahapan berbicara (talk) merupakan kesempatan bagi siswa untuk mengemukakan hasil tugas yang telah diperoleh pada tahapan berpikir (think). Dalam berdiskusi pada tahapan berbicara (talk) seharusnya kegiatan pembelajaran dapat berjalan dengan sangat antusias dan siswa dapat aktif selama proses pembelajaran berdiskusi. Tetapi, pada tahapan berbicara (talk), siswa tidak merasakan bahwa tahapan berbicara (talk) merupakan kesempatan bagi siswa dalam mengemukakan ide dan gagasan yang telah diperoleh dari kegiatan berpikir (think), karena kebanyakan siswa merasa gugup dan sulit untuk menyampaikan ide dan gagasannya kepada guru dan temantemannya. Hal ini dapat terjadi karena selama proses pembelajaran yang dilakukan biasanya hanya berpusat pada guru, dan siswa belum terbiasa untuk belajar berdiskusi untuk mengemukakan pendapatnya atau mengemukakan informasi yang telah diperoleh dari bahan bacaan.

Selama proses pembelajaran pada tahap berbicara (talk) kegiatan pembelajaran yang dilakukan oleh guru tidak sesuai dengan pendapat yang dikemukakan oleh Erina dkk., (2018:7) mengatakan bahwa tahapan berbicara (talk) merupakan kesempatan

Silampari Bisa: Jurnal Penelitian Pendidikan Bahasa Indonesia, Daerah, dan Asing Vol. 4, No. 2, 2021 
bagi siswa untuk melakukan diskusi dengan membagi siswa menjadi beberapa kelompok dengan jumlah setiap kelompok sebanyak 3-5 siswa. Hal ini terjadi karena proses pembelajaran selama dilakukannya penelitian sedang terjadi pandemi covid19, sehingga tidak memungkinkan guru untuk membagi siswa dalam beberapa kelompok belajar dengan jumlah setiap kelompok sebesar 3-5 siswa.

Proses pembelajaran tahapan berbicara (talk) pada pertemuan pertama dan pertemuan kedua yang dilakukan oleh guru, sudah cukup sesuai dengan teori yang telah dikemukakan. Tahapan berbicara (talk) yang dilakukan dengan tidak membagi siswa menjadi beberapa kelompok belajar, dapat mengakibatkan tidak terjadinya kerjasama antara siswa dalam mengerjakan tugas yang diberikan, sehingga siswa memiliki tanggung jawab secara individu dalam mengerjakan tugas yang diberikan oleh guru. Langkah pembelajaran yang dilakukan oleh guru selama proses berdiskusi dengan tetap memperhatikan siswa yang kurang aktif dalam proses diskusi sudah sangat tepat, guru tidak hanya fokus pada siswa yang aktif tetapi guru secara langsung memanggil siswa yang pasif dalam proses pembelajaran untuk ikut berpartisipasi dalam berdiskusi.

\section{c) Tahap Menulis (Write)}

Tahapan menulis (write) pada pertemuan pertama kegiatan yang dilakukan oleh guru yaitu dengan memberikan contoh surat pribadi yang telah diacak. Tugas yang diberikan oleh guru pada pertemuan pertama bertujuan untuk melihat sejauh mana pemahaman dan pengetahuan siswa mengenai struktur surat pribadi yang telah dipelajari pada tahapan berpikir (think) dan tahapan berbicara (talk). Kemudian pada pertemuan kedua, guru memberikan ilustrasi kepada siswa berupa instruksi untuk menulis surat pribadi. llustrasi yang diberikan oleh guru berguna untuk membangun imajinasi siswa dalam menulis surat pribadi, sehingga ide dan gagasan siswa dalam menulis surat pribadi dapat terfokus dengan baik.

Kegiatan pembelajaran yang terjadi pada pertemuan kedua, yaitu dengan guru memberikan masukan kepada dua siswa yang paling cepat dalam mengumpulkan surat pribadi yang telah ditulis oleh siswa. Saran atau masukan yang diberikan oleh guru merupakan saran yang terdapat pada paragraf penutup surat pribadi, kebanyakan siswa menggunakan kalimat yang kurang tepat dalam menulis paragraf penutup. Hal ini tidak sesuai dengan pendapat Yamin dan Ansari (2012:87) mengemukakan bahwa kegiatan menulis dapat memberikan kesempatan bagi guru untuk dapat mengetahui perkembangan dan pemahaman siswa mengenai materi pembelajaran yang sudah dilakukan. Tindakan yang dilakukan guru dengan memberikan saran kepada 2 siswa untuk memperbaiki kembali surat pribadi yang telah dibuat, menyebabkan guru tidak dapat melihat dan mengetahui secara keseluruhan mengenai kemampuan siswa dalam membuat surat pribadi.

Tahapan menulis (write) yang telah dilakukan sudah cukup sesuai dengan teori yang telah dikemukakan. Pada pertemuan pertama, langkah pembelajaran yang diterapkan oleh guru dengan memberikan tugas kepada siswa untuk menyusun surat pribadi dapat memberikan pembelajaran yang bermakna bagi siswa, karena proses pembelajaran dilakukan secara berulang-ulang dan siswa dapat menghubungkan pengetahuan yang telah diperoleh dari tahapan berpikir (think) dan tahapan berbicara (talk). Tetapi, tahapan menulis (write) pada pertemuan kedua dengan langkah pembelajaran yang diterapkan oleh guru kurang sesuai dan kurang tepat, karena guru memberikan masukan atau saran kepada beberapa siswa mengenai paragraf 
penutup dalam surat pribadi yang telah dibuat oleh siswa, sehingga guru tidak dapat melihat secara keseluruhan pemahaman siswa dalam menulis surat pribadi.

Pelaksanaan kegiatan pembelajaran dengan menerapkan model pembelajaran kooperatif think talk write diperoleh hasil kemampuan siswa dalam menulis surat pribadi. Terdapat tiga aspek penilaian yang dinilai dari surat pribadi yang ditulis oleh siswa, yaitu aspek kesesuaian isi surat pribadi, aspek struktur surat pribadi, dan aspek kaidah kebahasaan surat pribadi. Pertama yaitu mengenai aspek kesesuaian isi surat pribadi, terdapat tiga siswa yang menulis surat pribadi tidak sesuai dengan tujuan pengiriman surat, hal ini dapat terjadi karena siswa tidak memperhatikan guru saat memberikan perintah untuk menulis surat pribadi berdasarkan tujuan yang diinginkan dari surat pribadi yang ditulis.

Kedua yaitu mengenai aspek struktur surat pribadi, dalam penulisan struktur surat pribadi terdapat dua puluh empat siswa yang menulis surat pribadi mengenai nama pengirim dan tanda tangan yang diletakkan di bagian sebelah kiri bawah. Hal ini tidak sesuai dengan struktur surat pribadi menurut Semi (2014:20) dan Kosasih (2019:98) mengemukakan bahwa letak penulisan tanda tangan dan nama pengirim dalam surat pribadi biasanya terletak disebelah bawah kanan. Penulisan tanda tangan dan nama pengirim yang diletakkan siswa di sebelah kiri, disebabkan karena contoh yang terdapat dalam bahan bacaan yang diberikan oleh guru mengenai tanda tangan dan nama pengirim terletak di sebelah kiri, serta guru tidak menjelaskan mengenai cara penulisan tanda tangan dan nama pengirim dalam menulis surat pribadi.

Ketiga mengenai aspek kebahasaan dalam menulis surat pribadi. Secara keseluruhan siswa menulis surat pribadi dengan tidak memperhatikan kebahasaan mengenai ejaan dalam menulis, sehingga terdapat beberapa kesalahan penggunaan ejaan yang tidak sesuai dengan aturan ejaan bahasa Indonesia yang berlaku. Hal ini dapat terjadi karena guru tidak menjelaskan secara rinci mengenai penggunaan ejaan dalam menulis surat pribadi, serta bahan bacaan yang diberikan oleh guru mengenai ejaan dalam menulis surat pribadi tentang kata awalan dan kata depan tidak ada di dalam bahan bacaan.

Berdasarkan tiga aspek yang dinilai dari surat pribadi yang telah ditulis oleh siswa, maka diperoleh hasil menulis surat pribadi dengan rata-rata kelas sebesar 75,18 . Skor rata-rata yang diperoleh siswa termasuk dalam kriteria cukup. Perhitungan persentase ketuntasan klasikal siswa dalam menulis surat pribadi diperoleh hasil persentase ketuntasan belajar sebesar $75 \%$.

\section{Simpulan dan Saran}

Berdasarkan masalah yang telah diajukan, hasil yang diperoleh dari penerapan model pembelajaran kooperatif think talk write (ttw) dalam pembelajaran menulis surat pribadi pada siswa kelas VII SMP Pelita Kasih Kota Bengkulu, dapat disimpulkan sebagai berikut.

1. Penerapan model pembelajaran kooperatif think talk write dalam pembelajaran menulis surat pribadi siswa kelas VII SMP Pelita Kasih Kota Bengkulu yang dilakukan oleh guru dengan menggunakan teks surat pribadi sudah diterapkan dengan tiga tahapan model pembelajaran kooperatif think talk write, yaitu tahapan berpikir (think), tahapan berbicara (talk), dan tahapan menulis (write). Pada tahapan berpikir (think), guru membagikan bahan bacaan dan tugas yang harus dikerjakan oleh siswa. Pada tahapan berbicara (talk), guru secara langsung 
membimbing siswa untuk melakukan diskusi mengenai hasil catatan dan tugas yang telah dikerjakan oleh siswa, tanpa harus membagi siswa menjadi beberapa kelompok. Pada tahapan menulis (write), guru memberikan tugas yang harus dikerjakan oleh siswa secara individu untuk melihat kemampuan dan pemahaman siswa selama menerima dan mengikuti kegiatan pembelajaran.

2. Hasil belajar siswa kelas VII SMP Pelita Kasih Kota Bengkulu dengan menerapkan model pembelajaran kooperatif think talk write, memperoleh nilai rata-rata 75,18 yang termasuk dalam kategori cukup dan persentase ketuntasan sebesar $75 \%$ siswa yang memperoleh nilai minimal 70 atau mendapatkan nilai sesuai dengan Kriteria Ketuntasan Minimal (KKM).

Berdasarkan hasil penelitian yang telah diperoleh dari penerapan model pembelajaran kooperatif think talk write (ttw) dalam pembelajaran menulis surat pribadi pada siswa kelas VII SMP Pelita Kasih Kota Bengkulu, maka terdapat beberapa saran yang diberikan oleh penulis sebagai berikut.

1. Bagi Peneliti Lanjutan

Penelitian ini dilakukan baru sebatas mendeskripsikan penerapan model pembelajaran kooperatif think talk write yang dilakukan oleh guru bahasa Indonesia di SMP Pelita Kasih dan mendeskripsikan kemampuan menulis surat pribadi dengan tujuan pengiriman tidak resmi yang ditujukan kepada Kakak dan Nenek dengan tujuan meminta uang untuk membeli baju baru, sehingga peneliti lanjutan diharapkan dapat melakukan penelitian berdasarkan tujuan pengiriman pada jenis surat pribadi resmi.

\section{Bagi Guru}

Penelitian ini diharapkan dapat memberikan alternatif bagi guru yang menggunakan model pembelajaran kooperatif think talk write secara lebih terstruktur pada mata pelajaran Bahasa Indonesia agar kegiatan pembelajaran selanjutnya menjadi lebih baik, dan model pembelajaran kooperatif think talk write dapat digunakan pada materi pembelajaran selanjutnya, serta dapat digunakan oleh guru mata pelajaran yang lain.

\section{Daftar Pustaka}

Erina, E., Triani, S. N., \& Oktavia, W. (2018). Penerapan Model Think Talk Write untuk Meningkatkan Keterampilan Menulis Parafrasa Puisi pada Siswa SMK Negeri 3 Singkawang Tahun Ajaran 2016/2017. JP-BSI (Jurnal Pendidikan Bahasa Dan Sastra Indonesia), 3(1), 6-9. doi:10.26737/jp-bsi.v3i1.448.

Hamdayama, J. (2014). Model dan Metode Pembelajaran Kreatif dan Berkarakter. Bogor: Ghalia Indonesia.

Mesterianti, M., Simarmata, M. Y., \& Firtawati, S. (2019). Penerapan Model Think Talk Write untuk Meningkatkan Keterampilan Menulis bagi Siswa Sekolah Menengah Pertama. Edukasi: Jurnal Pendidikan, 17(1), 102. doi:10.31571/edukasi.v17i1.1083 


\section{Marinir Tu Meilani Simanjuntak, Arono, Noermanzah}

Penerapan Model Pembelajaran Kooperatif Think Talk Write (TTW) dalam Pembelajaran Menulis

Surat Pribadi pada Siswa Kelas VII SMP Pelita Kasih Kota Bengkulu

Huda, M. (2019). Model-Model Pengajaran dan Pembelajaran. Yogyakarta: Pustaka Belajar.

Kosasih, E. (2019). Dasar-Dasar Keterampilan Menulis. Bandung: Yrama Widya.

Minarsih, N. M. L., \& Putra, M. (2020). Pengaruh Model Pembelajaran Think Talk Write Berbantuan Media Tape Recorder terhadap Keterampilan Berbicara. Jurnal Pedagogi dan Pembelajaran, 3(1), 35-42. doi:10.23887/jp2.v3i1.24359.

Mulyani, R., \& Syahrul, R. (2019). Pengaruh Model Pembelajaran Kooperatif Tipe Think Talk Write (TTW) Berbantuan Media Audiovisual terhadap Keterampilan Menulis Teks Persuasi Siswa Kelas VIII SMP Negeri 8 Padang. Pendidikan Bahasa Indonesia, 8(3), 374. doi:10.24036/108222-019883.

Noermanzah, N., Abid, S., \& Aprika, E. (2018). Pengaruh Teknik Send a Problem terhadap Kemampuan Menulis Daftar Pustaka Siswa Kelas XI SMA Negeri 4 Lubuklinggau. Jurnal Kajian Bahasa, Sastra dan Pengajaran (KIBASP), 1(2), 172. doi:10.31539/kibasp.v1i2.273

Octavia, S. A. (2020). Model-Model Pembelajaran. Yogyakarta: Deepublish.

Putri, R. D., \& Syahrul. (2019). Pengaruh Penggunaan Teknik Think Talk Write (TTW) terhadap Keterampilan Menulis Teks Fabel Siswa Kelas VII SMP Negeri 31 Padang. Pendidikan Bahasa Indonesia, 8(2), 66-72. doi:10.24036/104513019883

Rabawati, K. (2020). Penerapan Model Pembelajaran Think-Talk-Write untuk Meningkatkan Kemampuan Memahami Ciri-Ciri Kebahasaan Teks Cerita Ulang Biografi. Mimbar IImu, 25(1), 141-148. doi:10.23887/mi.v25i1.24771

Semi, M. A. (2007). Dasar-Dasar Keterampilan Menulis. Bandung: Remaja Rosdakarya.

Sugiyono. (2016). Metode Penelitian Pendidikan. Bandung: Alfabeta.

Sumayyah, S., Mustadi, A., \& Harun, H. (2019). Penilaian Aktivitas Siswa dalam Keterampilan Menulis melalui Model Think Talk Write. Premiere Educandum: Jurnal Pendidikan Dasar dan Pembelajaran, 9(1), 23. doi:10.25273/pe.v9i1.3966

Tarigan, H. G. (2013). Menulis sebagai Suatu Keterampilan Berbahasa. Bandung: CV Angkasa.

Zuhriandini, K. (2020). Analisis Kemampuan Menulis Surat Pribadi Siswa Kelas V SDN 26 Pekanbaru. Primary: Jurnal Pendidikan Guru Sekolah Dasar, 9(1), 4146, doi:10.33578/jpfkip.v9i1.7836 